9. 'Note on the Occurrence of Mammoth Remains in McLennan County;' by Professor O. C. Charlton, Baylor University.

10. 'The Hydrographic Survey of-Texas,' by Professor T. U. Taylor, University of Texas.

11. 'Theorem concerning Centers of Curvature of a Roulette' (by title), by Dr. M. B. Porter, Yale University, New Haven, Conn.

12. 'On the Floral Provinces and Vegetative Formations of the West Texas Region' (by title), by Dr. William L. Bray, University of Texas.

Frederic W. Simonds,
University of Texas.

\section{ENGINEERING ASSOCIATION OF THE SOUTH.}

THE regular monthly meeting of the Association was held on the evening of January 10th, at Vanderbilt University.

The death of Maj. Niles Meriwether, President of the Association was announced, and Messrs. J. S. Walker and Hunter McDonald were appointed a committee to prepare a memorial sketch of his life. The Association will feel most keenly this loss, for Maj. Meriwether has been a most active member.

A communication from Mr. J. C. Truatwine, Jr., Secretary of the 'Journal of Association of Engineering Societies,' was read. After some little discussion it was the unanimous opinion that the continuance of an individual publication was far preferable to uniting with the ' Journal of the Association of Engineering Societies,' and the Secretary was instructed to so notify Mr. Truatwine.

The first paper was a description of the methods of doing some bridge pier and foundation work in Chemulpo, Korea, by W. H. Holmes, an American engineer who has recently returned from that country. The system of keeping records of rivers in that ancient country was briefly described. They extended back into the past for many centuries and are said to be very accurate: Mr. Holmes stated that where an opportunity offered itself for a check the records were in every case sustained. The record for the river in question extended back 509 years and explanation was made at the beginning of the records that the history of the river previous to that time had been consumed in a fire which had burned the house and all contents.
The second paper was presented by Mr. Julian W. Kendrick, city engineer of Birmingham, Ala. It was an exhaustive study of the sewerage problem now confronting the Birmingham district. The geographical features of the drainage area were described, the difficulties in carrying out the various methods of sewerage set forth, and finally a plan proposed. The paper had been carefully prepared and was an interesting contribution on the sewerage question.

H. M. JoNEs, Secretary.

\section{VERMONT BOTANICAL CLUB.}

$\mathrm{AT}_{\mathrm{T}}$ the annual winter meeting of the Club on January 25th and 26th the following program was presented:

'The Finding of a Plumose Variety of Asplenium ebeneum,' by Mrs. Frances B. Horton.

'Some Common Confervæ,' by T. F. Hazen, Columbia University.

'Some Interesting Mosses Collected in Vermont in 1901,' by Dr. A. J. Grout, Boys' High School, Brooklyn.

'Are there Two Kinds of Hemlock in Vermont'? by Elroy C. Kent.

'Note on Tremella mycetophila Pk.,' by Dr. E. A. Burt. Middleburg College.

' Notes on the Last Season's Botanizing,' by Mrs. Nellie F. Flynn.

'Report of Progress on the Maple Sap Problem,' by

A. B. Edson, University of Vermont.

'The Flora-What Next?' by Clifton D. Howe, University of Vermont.

'The Present Status of Vermont Botany,' by President Ezra Brainard, Middleburg College.

'A Botanical Trip to Joe's Pond,' by Mrs. Carrie E. Straw.

'Botanizing in the Bermudas, ' by Dr. M. A. Howe, Columbia University.

"What Text-book of Botany shall be used in the High School?' by Miss Phoebe Towle.

'Wild Violets in the Garden,' by Miss E. Mabel Brownell.

'Are the Equisetums or Ferns Poisonous?' by Professor L. R. Jones, University of Vermont.

C. D. Dixlowe, Secretary.

\section{DISCUSSION AND CORRESPONDENCE.}

A BIBLIOGRAPHIC CATCH TITLE FOR EVER AND EVER.

Professor MARK's method of referring to bibliographic lists by name of author and number of year is worthy of general adoption; but it is not surprising that a difficulty should be 
met with when an attempt is made to depart from the principle of the method by the introduction of an arbitrary symbol. Professor Mark (SCIENCE, January 4, 1901) proposes that the sixteen hundreds shall be denoted by 1600 , etc., the seventeen hundreds by 1700 , etc., the eighteen hundreds by '00, etc., and the nineteen hundreds by :00, etc. This method could be of value only if accepted universally, or at least by all scientific writers. The confusion introduced by inadvertently writing ' 23 for 1923 will be as great as if one had actually written 1823. But is it likely that this confusion will be avoided, seeing that many people already have dated letters and so forth' 00 or ' 01 , meaning 1900 and 1901? Setting this objection aside for the present, we note what difficulty Professor Mark has in finding a suitable symbol for the nineteen hundreds, and we wonder what is to be done with the next century, and with the one after that, and so on. If we are to settle this question in a scientific spirit, let us attempt something better than an apostrophe for 18, a colon for 19, a hyphen, say for 20 , a dagger for 21 , and such arbitary methods, all for the sake of saving an $\mathrm{em}$ space here and there or a few tenths of a second per annum. The irritation induced by the constant repetition of 18 or 19 is the least of the penalties we have to pay for the possession of ten fingers, and it is hardly enough to induce us to attempt yet once more some new method of notation. I therefore dismiss as impracticable all suggestions that familiar numerals should arbitrarily or even with some show of reason be replaced by punctuation marks, or by letters of any alphabet, or by ideographs, or by musical notes. But, seeing that the majority of papers referred to by any writer are, and in most cases will be, those of the hundred years immediately preceding the date of his own writing, I suggest that the apostrophe should be used, by those who like such self-saving devices, for all those years and for them alone. Professor Mark when he wrote in 1899 used the apostrophe for all the years 1800 to 1899 . In 1901 let him use it for the years 1802 to 1901 ; in 1923 , if, as we hope, he be still active, let him use it for the years 1824 to 1923 . This plan seems to be more in accord with general usage. 'Who fears to speak of '98'? did not cease to be intelligible to everyone, until the year '98 again came round. For all years more than a hundred back, or in any case of doubt, let us use the full number; and more particularly should it be used in the dating of important letters, of pub lications, and of formal entries in museum registers, or similar volumes of permanent historic importance.

F. A. BAther.

\section{Natural History Museum, London, ENGLAND.}

\section{A FURTHER APPEAL TO ALL LOVERS OF BIRDS.}

ONE year ago all the sea birds breeding along our coasts seemed doomed to extinction at the hands of the milliners, in spite of their beauty and incalculable services as scavengers, and as guides to fishermen and mariners.

The American Ornithologists' Union, alarmed at the prospect, appointed a special committee to devise means for the preservation of these birds. This committee, aided by the press, appealed to the bird-loving public for funds with which to hire wardens to guard the sea birds while they were on their breeding grounds.

The contributions received in response to this appeal were sufficient to secure faithful wardens for the protection of all the colonies still left on the coast from Cape Charles, Virginia, northward to Maine.

The encouraging results of the efficient protection given the birds during the season of 1900 prompts the American Ornithologists' Union to continue its efforts during the coming breeding season and to extend, if possible, the work to the South Atlantic and the Gulf coasts, where there is even greater need of bird protection than in the north.

At the last session of Congress a Federal law was enacted, known as the Lacey Act, which gives by far the strongest protection ever furnished to bird or beast in the United States, as it makes it a punishable offense to export from a State any bird or animal unlawfully killed therein, or to receive such bird or animal in any other State. The common carriers are even now refusing to transport birds and animals in view of the heavy penalty attached to a violation of the Lacey law. It is believed by the committee that the vigorous enforcement 